Collection: EFI 2008 Annual Conference Week - Orvieto (Italy) Adaptation of Forest Landscape to Environmental Changes Guest Editor: Giuseppe Scarascia Mugnozza (CRA - Rome, Italy)

\title{
The Polish landscape changing due to forest policy and forest management
}

\begin{abstract}
Mederski PS ${ }^{(1)}$, Jakubowski $M^{(1)}$, Karaszewski Z ${ }^{(2)}$
This paper presents an analysis of policy application in Poland affecting landscape and forest management changes designed for an ecological restoration. "Ecological" policy was introduced in Poland in 1991 (Bill on Forests) and 1995-1999 (Decree 11 and 11A). To analyse the effectiveness of the policy and its impact on landscape change, the study uses five selected indicators: 1) species distribution, 2) methods of final felling, 3) forest functions in terms of protection and economic role, 4) cost structure and 5) wood production. The analysis shows that some of the ecological ideas were applied years before official documents were issued: species composition change, in favour of broadleaves has been carried out since 1945; since 1975, considerable growth in protective areas has been observed, doubling from 22.5 to $47.5 \%$ by 2006 ; timber resources have also grown by $50 \%$ in the last 35 years. After 1991, when the new policy was introduced, change in these indicators was more rapid. More direct and visible examples of policy applications in the last 15 years are observed in 1) the reduction of clearcuts: in 2005 this was at its lowest level in comparison with the previous 15 years and amounted to $19.9 \% ; 2$ ) the focus on protection: the cost of forest and fire protection in 2006 was the third largest expense in the State Forests budget, special attention was paid to reconstruction in order to increase water retention, 3 ) the afforestation process: this has doubled in intensity in the last decade compared with the previous decade. Nevertheless, organised landscape change is also accompanied by natural calamities, of which fires and windbreaks are most severe.
\end{abstract}

Keywords: Landscape change, Forest policy, Ecological restoration

\section{Introduction}

After nearly 200 years of experience with high volume wood production in coniferous stands, it has been observed that continuous (and coniferous) forestry is at risk and is not sustainable or environmentally friendly. This conclusion was derived when the health of declining stands was observed and there

(1) Department of Forest Utilisation, Poznan University of Life Sciences, ul. Wojska Polskiego 71A, 60-625 Poznan (Poland); (2) Forest District Czarnobór, The State Forests, Czarnobór 1, 78-400 Szczecinek (Poland)

\section{(a) Piotr Mederski}

(piotr.mederski@up.poznan.pl)

Received: Apr 08, 2009 - Accepted: Apr 09, 2009

Citation: Mederski PS, Jakubowski M, Karaszewski Z, 2009. The Polish landscape changing due to forest policy and forest management. iForest 2: 140-142 [online: 2009-07-30] URL:

http://www.sisef.it/iforest/show.php? id $=503$ were higher expectations from non-wood forest products such us environmental and social functions. A report from the World Commission on Environment and Development (United Nations 1987) states that one of the main factors of sustainable development is the integration of economic and ecological objectives in every process of decision-making in the economy.

For the most part, during the last century, forestry was considered as a source of timber production. In Poland, during the economic development after 1945, management in forestry was firstly focused on timber production, and secondly on sustainability and ecological principles. New trends in the world and the changing role of forests moved the focus to: 1) environmental issues, seen as the most important; and if possible, 2) wood production. The Parliament document "Bill on Forests" issued in Poland in 1991 introduced a new kind of forest management, taking into consideration all known forestry practices but in a new order: 1) preservation, 2) protection, and 3) enlargement of forest resources in conjunction with other environmental issues and the national economy (Anonymous 1991). This was a new way of using a well-known tool and the starting point of a new strategy leading to ecological restoration and resulting in landscape change.

After the introduction of the above-mentioned "Bill on Forests", a new document was published in 1995 for forest practitioners: Decree no 11, updated in 1999 to Decree no $11 \mathrm{~A}$, issued by the State Forests (Anonymous 1999). The document was put together after wide discussion within the country and at an international forum which included Polish representatives. The main objective of this document was to improve forest management, conducted along ecological guidelines, and sustainability, with the following order of principles: 1) the preservation of forest productivity; 2) the maintenance of the health and vitality of forest ecosystems; 3 ) the protection of soil and water resources in forests; 4) the maintenance and growth of the forest in order to contribute to the global carbon cycle and carbon sequestration; 5) the long-term strategy for multidimensional social and economic benefits from forests.

Research presented in this paper focuses on data regarding five main areas of Polish forestry affecting landscape change. This limited selection of five main activities in the forestry sector is necessary in order to draw a sensible conclusion without analysing too many aspects of the forestry sector. The most often analysed changes in forestry in studied literature are changes in afforestation, which is the most dynamic and measurable indicator of landscape change. Afforestation linked to silviculture and management is also affected by policy and economics. Saarinen et al. (2001) compared landscape changes in Finland and Russian Karelia. The considerable differences revealed are explained by different forms of management, species composition and political and economic factors. Apart from afforestation, landscape change is analysed by many more factors (Guirado et al. 2007, Gustafson et al. 2007, Hernandez-Stefanoni 2005, Grossmann \& Mladenoff 2007, US-NRC 2008).

In Europe afforestation has been growing over the last decades and is expected to have grown by $5 \%$ by 2020 (UNECE/FAO 2005). It is also observed in Turkey (Çakir et al. 2008), but not, e.g., in China (Guofu \& Shengyan 2006, FAO 2005) and in South America (FAO 2005).

The aim of this paper is to present the success story of how Decree 11 and "Bill on Forests" have been put into practice to ensure the ecological restoration of forests in Poland and the impact on landscape change. This analysis is based on the following 5 in- 
dicators, which have gradually changed since the introduction of Decree 11 and $11 \mathrm{~A}$ : 1) species distribution; 2) methods of final felling; 3 ) forest functions in terms of protection and economic role; 4) cost structure; 5 ) wood production. The analysis of change is based on statistical data and reports concerning forestry in Poland (Anonymous 2006, 2007, 2008)

The analysis of the five selected indicators characterising landscape change is based on statistical data taken from the last ten or more years. Comparison of this data, characterising landscape in the past and currently, shows the dynamics of change.

\section{Analysis of selected indicators}

\section{Species distribution}

In the ' 40 s and ' 50 s of the last century stand species composition was based on pine, spruce and larch. However, the poor condition of these stands required the conversion of coniferous stands to mixed or broadleaved stands. This practice was also applied in other European countries: the Czech Republic, Germany, the UK and Slovakia. Pure timber production in even-aged stands consisting of one species has proved to be unprofitable in the long run. In the period 1945-2006 the species structure in Poland's forests underwent substantial change; in this period the share of broadleaved species increased from $13.0 \%$ to $23.6 \%$ (planned $33 \%$ by 2050 - Anonymous 2007).

\section{Methods of final felling}

Before 1990 clear cuts on 6 ha single plots were generally carried out. In even-aged pine stands it was the least expensive and least time-consuming practice. The new approach considering new silvicultural practices leads to smaller clear cut plots as well as their limited frequency. More than $43 \%$ of merchantable timber was obtained in tending cuts. There was a rise in the volume of timber obtained in incidental felling by almost $2 \%$ compared with in 2004 , while the volume of timber harvested in clear-cuts decreased by $2 \%$. The clear-cutting system in 2005 was at its lowest level in comparison with the previous 15 years (Anonymous 2008).

Forest functions - protection vs. economic role

In the period 1975-2006, the protective area in the total area of the State Forests doubled in size from $22.5 \%$ to $47.5 \%$ (Anonymous 2007). Areas of reserves have expanded five times in almost the same period of time and their share of the general forest area increased from $0.3 \%$ to $1.1 \%$ (Anonymous 2007). Additionally, the number of environmentally valuable trees ("environment- al statues") in the last ten years increased considerably from 26423 (in 1995) up to 34989 (in 2005 - Anonymous 2007). A proecological attitude is also represented in creating Promotional Forest Clusters - selected fragments of forest showing the good effects of multifunctional forest management. These Clusters are used for education of society and act as examples of multifunctional forestry for other parts of the country.

\section{Cost structure}

As the lack of water was noticed by a State Forests NFH in the years 1997-1998; from then until 2005, 1005 new water containers, covering 1287 ha appeared and 1950 accumulating constructions for the price of PLN 32.7 million were built; in 2006 more than 100 retention containers were built on an area of approx. 70 ha and 300 small retention objects (gates, cataracts, culverts, etc.) were established. The total cost of the construction amounted to PLN 5.8 million. It is planned that activities related to small retention in forests will be carried out in the next few years (Anonymous 2007).

\section{Wood production}

At the beginning of 2005 , the estimated timber resources in forests managed by the State Forests NFH amounted to 1586 million $\mathrm{m}^{3}$ of gross merchantable timber, which means that in the last 35 years, growth is observed at about $50 \%$. As the growth of timber took place, the amount of harvested wood has also grown: since 1996 by $5 \%$ per year (growth by about $50 \%$ in 10 years - Anonymous 2006).

The basis for all the afforestation activities in Poland is the National Programme for the Augmentation of Forest Cover (KPZL) adopted by the Council of Ministers on 23 June 1995. The Programme anticipates an increase in forest cover to $30 \%$ by 2020 and $33 \%$ by 2050 (Anonymous 2006). The average area of farmlands and wastelands within the State Forests NFH afforested between 1986 and 1993 was 3900 hectares annually. Thanks to the subsidies from the state budget and a loan from the European Investment Bank, the afforestation process, after the adoption of the KPZL, could be accelerated. The area afforested reached 9800 hectares in 1994,13000 hectares in 2000, and 9700 hectares in 2004. The year 2005 saw a decline in the afforestation rate to 6200 hectares. In 1995-2005, the average area of afforested land in the State Forests NFH was 10500 hectares per year (Anonymous 2006).

\section{Discussion}

Taking into consideration the five selected indicators, considerable ecological change in the landscape is observed. A new attitude towards forest management expressed in "Bill on Forests" and Decree no 11A has been ap- plied in Polish forestry and the best ecological practices have been introduced. Some of this environmentally friendly approach was carried out before the documents were formed: species composition change in favour of broadleaves has been carried out since 1945 ; since 1975 a considerable growth in protective areas has been observed, which doubled from 22.5 to $47.5 \%$, by 2006 ; also timber resources have grown by $50 \%$ in the last 35 years. After the appearance of the new policy, the growth in these parameters only intensified (Anonymous 2006, 2007).

More direct and visible examples of policy applications in the last 15 years is observed in the reduction of clear felling, focusing on intensive forest protection (revealed in funds spent for fire protection and water retention) as well as afforestation. Clear felling in 2005 was at its lowest level in comparison with the previous 15 years and amounted to $19.9 \%$ (Anonymous 2008). The cost of forest and fire protection in 2006 was the third largest expense in the State Forests budget; special attention was also paid to reconstruction in order to increase water retention. The afforestation process has doubled in intensity in the last decade compared to the previous decade (Anonymous 2006).

Apart from organised, positive and expected modification in nature, there are also calamities seriously affecting the landscape, especially windbreaks and fires. These disasters, caused mainly by abiotic but also by biotic factors, have an impact on the forestbased sector economy, and eventually on the national economy. On post-disaster areas different forms of management have been applied, such as the preservation of timber and/or immediate reforestation. Original landscape change (from the silvicultural point of view) takes place when no action (as a solution for recovery from calamities) can be taken, e.g., stands broken by the wind in north-east Poland in 2004 left for natural succession. Thomas R. Crow's publication presents the trial of landscape modelling by nature, mainly in North America (Crow \& Perera 2004). A similar attitude is presented by James D. Wickham in relation to inhabiting forest areas (Wickham et al. 2000). Following ecological policy positively affects landscape change. The study shows that knowledge and experience in silviculture and forest management is also a drive in ecological restoration. However, nature has its own policy put into practice in the form of calamities, which effectively changes the landscape without human intervention.

\section{Conclusion}

Since 1945 species composition has changed from 13.0 to $23.6 \%$ in favour of broadleaves.

Clear felling in 2005 was at its lowest level in comparison with the previous 15 years 
and amounted to $19.9 \%$.

In the period 1975-2006, the protective area in the total area of the State Forests doubled from 22.5 to $47.5 \%$.

The cost of forest and fire protection in 2006 was the third largest expense in the State Forests budget; special attention was and is being paid to reconstruction in order to increase water retention.

Timber resources have grown by $50 \%$ in the last 35 years, timber harvesting has grown by $50 \%$ in the last 10 years; the afforestation process has doubled in intensity in the last decade compared to the previous decade.

\section{References}

Anonymous (1991). Ustawa o Lasach. Bill on Forests. [online] URL: http://www.lp.gov.pl/media/biblioteka/podstawy/ustawa_o_lasach/?

searchterm $=$ None

Anonymous (1999). Zarządzenie 11A. Decree 11A. [online] URL: http://www.eko.org.pl/lkp/ prawo html/zarzadzenie 11A.htm

Anonymous (2006). The state forests in figures. General directorate of the state forests. CILP, Warszawa (Poland). [online] URL: http://www. lp.gov.pl/media/biblioteka/in_english/state_fores ts in figures2004.pdf

Anonymous (2007). Forests in Poland. CILP, Warszawa, Poland.

Anonymous (2008). Central Statistical Office,
Warszawa, Poland.

Cakir G, Sivrikaya F, Keles S (2008). Forest cover change and fragmentation using Landsat data in Maca state forest enterprise in Turkey. Environ. Monit. Assess. 137: 51-66. - doi: 10.1007/ s10661-007-9728-9

Crow TR, Perera AH (2004). Emulating natural landscape disturbance in forest management - an introduction. Landscape Ecology 19: 231-233. doi: 10.1023/B:LAND.0000030762.86156.5d

FAO (2005). Global forest resources assessment. FAO Forestry Paper 147, Rome. [online] URL: http://www.fao.org/DOCREP/008/a0400e/a0400 e00.htm

Grossmann EB, Mladenoff DJ (2007). Open woodland and Savanna decline in a mixed-disturbance landscape (1938 to 1998) in the northwest Wisconsin (USA) Sand Plain. Landscape Ecology 22: 43-55. - doi: 10.1007/s10980-0079113-7

Guirado M, Pino J, Rodà F (2007). Comparing the role of site disturbance and landscape properties on understory species richness in fragmented perubian Mediterranean forests. Landscape Ecology 22: 117-129. - doi: 10.1007/s10980-0069009-y

Guofu L, Shengyan D (2006). Driving factors of forest landscape change in Yiluo River basin. J. Geographical Sciences 16 (4): 415-422. - doi: 10.1007/s11442-006-0404-8

Gustafson EJ, Lytle DE, Swaty R, Loehle C (2007). Simulating the cumulative effects of mul- tiple forest management strategies on landscape measures of forest sustainability. Landscape Ecology 22: 141-156. - doi: 10.1007/s10980-0069017-y

Hernandez-Stefanoni JL (2005). Relationships between landscape patterns and species richness of trees shrubs and vines in a tropical forest. Plant Ecology 179: 53-65. - doi: 10.1007/s11258 -004-5776-1

Saarinen K, Jantunen J, Saarnio S, Kuitunen K, Marttila O (2001). Effects of land use changes on the landscape composition: a comparison between Finnish and Russian Karelia. Environment, Development and Sustainability 3: 265 274. - doi: 10.1023/A:1020819118304

United Nations (1987). Report of the world commission on environment and development: our common future. [online] URL: http://www.undocuments.net/wced-ocf.htm

UNECE/FAO (2005). European forest sector outlook study. United Nations, Geneva, Switzerland. [online] URL: http://www.unece.org/timber/efsos/EFSOS_finaldraft.pdf

US National Research Council (2008). Hydrologic effects of a changing forest landscape of the committee on hydrologic impacts of forest management. The National Academies Press, Washington, USA, pp. 180.

Wickham JD, O'Neill RV, Jones KB (2000). Forest fragmentation as an economic indicator. Landscape Ecology 15: 171-179. - doi: 10.1023/ A:1008133426199 